\title{
AZ ÖTVENEN TÚLIAK, MINT NÖVEKVŐ JELENTŐSÉGÚ CÉLCSOPORT
}

Nemzetközi és hazai kutatási eredmények jelzik, hogy az ötvenen túli fogyasztók gazdasági jelentősége egyre növekszik. Ezért a vállalatoknak marketingstratégiájuk kialakításánál erre a korosztályra is gondolniuk kell. A szerzó cikkében szakirodalmi ered mények és egy kérdốives felmérés ${ }^{1}$ alapján jellemzi e célcsoportot, kiemelten foglalkozik a vásárlási stílussal, a nosztalgiaérzéssel, az értékekkel, a szabadidős tevékenységekkel, valamint a reklámmal szembeni attitüdökkel. Következtetéseket von le a célcsoportképzés és a marketingkommunikáció vonatkozásában.

Kulcsszavak: célcsoport, marketingstratégia, marketingkommunikáció

A népesség elöregedése egész Európát jellemzi, és ez a folyamat előreláthatólag a jövőben is folytatódik. Számítások szerint néhány évtized múlva egyes országokban a 60 éven felüliek aránya megközelíti majd a 40\%-ot. Magyarországon 2050-re a 60 éven felüliek a népesség 36\% teszik majd ki (S. Molnár, 2004). E változásnak természetesen számos makrogazdasági következménye is van, amelyek leginkább a nyugdíj-, illetve az egészségügyi ellátást érintik leginkább, azonban a mikrogazdasági hatások is figyelemre méltóak. A kitolódó életkornak egyik következménye, hogy a fejlett országokban az ötvenen felettiek számosságukat és vásárlóerejüket tekintve is egyre vonzóbb piaci célcsoporttá válnak.

A Deloitte tanácsadó cég 2005-ben készült felmérése (Wealth with Wisdom, Serving the Needs of Aging Consumers, www.deloitte.com) szerint az ötvenedik életévüket betöltött fogyasztók egyes országokban akkora gazdasági erốt képviselnek, hogy egész iparágak fejlödését meghatározzák. Az Amerikai Egyesült Államokban az ötvenen túliak a teljes fogyasztói kiadások felét adják. Az egészségvédelemtől kezdve a kiskereskedelemig, az utazástól a pénzügyi szolgáltatásokig, a szórakoztatástól az elektronikai cikkekig az idơsödố vásárlók egyre inkább elvárják, hogy saját igényükre szabott termékek álljanak rendelkezésükre. Ha figyelembe vesszük, hogy az idősebb fogyasztók száma milyen mértékben növekszik, belátható, hogy a vállalatoknak fel kell készülniük szemléletmódjuk és marketinggyakorlatuk megváltoztatására.
Magyarországon a hirdetốk nagy része még nem közeledik az ötvenen túliak célcsoportjához. A BMB Focus kutatásvezetôje ${ }^{2}$ ezt azzal magyarázza, hogy a vállalatok úgy vélik, az idősebbek, bár lojálisak, rögzült szokásokkal bírnak, akkor vesznek valamit, ha a régi tönkrement. A divat kevésbé befolyásolja vásárlási döntéseiket. Másrészt, akik a reklámokat készítik, legalább két generációval fiatalabbak e célcsoportnál, és kevés empátiát mutatnak az idősebbek irányában. A globális vállalatok azonban ma már egyre inkább odafigyelnek az idősödő fogyasztók igényeire. Négy dimenzió határozza meg az idősebb fogyasztók magatartását.

A biologiai dimenzió utal arra, hogy az idóvel az emberi szervezet változik, a látás, a hallás az idô múlásával gyengül. Ezek a változások befolyásolják a környezetból származó ingerek észlelését, és a reklámok, eladáshelyi ösztönzók tervezésénél ezt figyelembe kell venni. A külsớ megjelenés változását is alapvető́en befolyásolja a kor, amit sokan próbálnak minél inkább kitolni az időben. Az anti-aging termékek piaca hihetetlen mértékben növekszik. 2003-ban a növekedési üteme $13 \%$ volt, szemben az elózó évek 4-5\%-os rátájával. ${ }^{3}$

A pszichologiai dimenzió fejezi ki azokat a változásokat, amelyek a kognitív képességeket, az attitứd kialakulását és változását, a hangulatot és az érzelmeket érintik. Általában jellemzó, hogy az ötvenen túliak kevésbé képesek az ingerek terén a ,zaj” vagy más irrele- 
váns stimulus elkülönítésére. A túlságosan ingergazdag reklám, amely vonzó a fiataloknak, az idősebbek számára kimondottan zavaró és hatástalan lehet. Az új információk elsajátításának üteme is lassabb, ami nem azt jelenti, hogy az idősödő fogyasztók nem képesek az új befogadására, de ehhez több időre van szükségük.

$\mathrm{Az}$ idősödő fogyasztók gazdasági helyzete is megváltozik, erre utal a gazdasági dimenzió. Általános feltételezés, noha empirikusan nem teljes mértékben bizonyított, hogy idósebb korban az emberek a korábbi évek alatt keresetükból tett megtakarításaikból költekeznek. Egy kutatásból ${ }^{4}$ azonban kiderült, hogy az idősebb emberek pénzügyi felkészültsége elmarad a kívánatostól. A 45 év felettiek gyakran egyáltalán nem ismerik az alapvető pénzügyi és befektetési fogalmakat. Kevesen vannak tisztában azzal is, hogy a befektetési portfólió diverzifikálása csökkenti a kockázatot, és gyakran a barátokat, családtagokat tekintik fő információforrásnak pénzügyi döntéseiknél.

A biológiai, pszichológiai és gazdasági változások mellett az idősebb fogyasztók társadalmi környezete is jelentósen megváltozik. A modellben a társadalmi dimenzió utal az emberek kapcsolati hálójának változásaira. Általában elmondható, hogy az életkorral bóvül az emberek kapcsolati háloja, és az sokkal összetettebbé válik. A fogyasztási döntések ezért gyakran nem egyéni, hanem kollektív döntések, amelyeket a családtagok és a kapcsolati háló más tagjai is befolyásolnak.

Noha az idősödó fogyasztók számának alakulása jelentős piaci lehetőséget sejtet, két szempontot mindenképpen figyelembe kell venni. Egyrészt az idősödő fogyasztók gazdasági ereje a világ különbözó részein igen eltérô. Nem kevés olyan ország van, ahol az idős kor a korábbi fogyasztás jelentős csökkenésével jár együtt. Magyarországrol megállapíthatjuk, hogy összességében az idős emberek életminősége függ (Keszthelyiné, 2004) koruktól és egészségi állapotuktól, háztartási viszonyaiktól (egyedül vagy házastársukkal, élettársukkal élnek, eltartottakról kell-e gondoskodniuk stb.), vagyoni és jövedelmi helyzetüktől, a tágabb baráti és családi környezettól kapott anyagi és nem anyagi támogatásoktól és a települések adta lehetôségektól (infrastrukturális kiépítettség, jövedelemkiegészítés lehetősége stb.). Azt azonban kijelenthetjük, hogy az idősebb emberek gazdasági potenciálját teljes mértékben figyelmen kívül hagyó vállalati stratégia hosszú távon nem lehet eredményes.

Másrészt az idősödő fogyasztók igen heterogén és összetett csoportnak tekinthetớk. Általában jellemzó, hogy a preferenciáik összetettek, és a múltbéli fogyasztásuk nem közvetlen jelzője jövőbeli fogyasztásuknak. E csoport heterogenitására utal a szakirodalomban használt elnevezések sokszínúsége is. A marketinggyakorlatban a hirdetốk a 18-49 éves életkorcsoportra összpontosítanak, jelen tanulmányunkban ezért foglalkozunk kiemelten az 50 év felettiekkel. Az életkori határok más szakirodalmi forrásokban sem egyértelmúek. Törốcsik Mária (2003) például a 45 év felettieket az „életet újrafogalmazók” néven tárgyalja, utalva arra, hogy a fogyasztók az idősebb kor határát közelítve érzékenyek a korukra, nehezen tudnak azonosulni saját élethelyzetükkel. A képet az is ámyalja, hogy az egyes emberek életíve igen eltéró lehet. Vannak olyanok, akik negyvenes éveikben már felnő́tt, önálló életet élő gyermekekkel rendelkeznek, mások pedig ebben az életkorban még gyermeket szülnek. A szerző az idős vagy idősödó jelzók helyett inkább a szenior megnevezést javasolja, hiszen ehhez a szóhoz nem kötődnek negatív asszociációk.

Objektív meghatározás hiányában, és talán a marketinggyakorlat számára is jol használható megközelítés a fogyasztó szubjektív értékelésére támaszkodni. Több szerzó (Barak, 1987; Barak et al., 2001), is hangsúlyozza, hogy az „öreg” és a „fiatal” relatív fogalmak, és ezért a kognitív kor kifejezés használatát javasolják. Barak (1987) szerint a kognitív kor egy többdimenziós konstrukció, amely a következó dimenziókból áll:

- feel age - hány évesnek érzi magát,

- look age - hány évesnek néz ki,

- do age - mivel foglalkozik,

- interest age - mi érdekli.

Underbill és Cadwell (1984) kutatásai szerint a 3040 évesek számottevó hányada átlagosan kilenc évvel érezte magát fiatalabbnak a tényleges életkoránál. Az évek múlásával a tényleges és a kognitív kor közötti különbség még tovább növekszik.

$\mathrm{Az}$ ötvenen túliak célcsoportjának megismerését segíti, ha megnézzük, hogy más kutatásokban milyen ismérvek alapján különböztettek meg e korosztályon belül szegmentumokat. Kézenfekvő az életkor alapján történó differenciálás, ami alapján megkülönböztethetünk fiatal időseket (pl. -70-es évekig), és idős időseket (pl. 70 év felett). Ennél gyakrabban alkalmaznak azonban értékek és viselkedésbeli szegmentációs ismérveket (Bone,1991).

Az l. táblázatban foglaljuk össze a jellegzetes szegmentációs kutatások eredményeit.

Az idősebb fogyasztók számára nagy jelentőséggel bír a vásárlás környezete. Mivel a kiskereskedelmi környezet egyre összetettebbé válik, vizuálisan gazdagodik, az idősebb fogyasztók számára nehezebb lehet az eligazodás (kognitív dimenzió). Nem véletlen, hogy ragaszkodnak a megszokott boltokhoz, és nem szíve- 
Szegmentációs kutatások

\begin{tabular}{|c|c|c|}
\hline Csoportok & Ismérvek & Szerzôk \\
\hline $\begin{array}{l}55-64 \text { idősebb } \\
65-74 \text { idős } \\
75-84 \text { koros } \\
85-\text { nagyon öreg }\end{array}$ & Tényleges életkor & Kramer, 1987 \\
\hline $\begin{array}{l}\text { Fiatal öreg } \\
\text { Öreg öreg }\end{array}$ & $\begin{array}{l}\text { Tényleges életkor } \\
\text { (nyugdij után) }\end{array}$ & Neugarten, 1982 \\
\hline $\begin{array}{l}\text { go goes (nem érzik magukat idősnek, önmegvalósító törekvések, } \\
\text { megfelelô anyagiak, szabadidős aktivitás) } \\
\text { slow goes (minőség, stabilitás fontos, konzervatív márkaválasztás) } \\
\text { non goes (egészségügyi problémák, gyakran egyedül élốk, } \\
\text { testi-szellemi problémák megoldása) }\end{array}$ & $\begin{array}{l}\text { Magatartás, } \\
\text { szubjektív korészlelés }\end{array}$ & Karmasin, 1995 \\
\hline $\begin{array}{l}\text { Master consumer (50--59 éves aktív életük csúcsán, jó jövedelemmel bírók, } \\
\text { inkább magukra és nem gyermekeikre költenek) } \\
\text { Maintrainer (60-69 éves, inkább passzív, gondolkodásban, vásárlásban } \\
\text { konzervatív, jól érzik magukat a munka terheitól való megszabadulás miatt) } \\
\text { Simplifier (70 év felett, sztereotíp nyugdíjascsoport) }\end{array}$ & Magatartás, Eletstílus & $\begin{array}{l}\text { Grey } \\
\text { Reklámügynökség, } \\
1998\end{array}$ \\
\hline $\begin{array}{l}\text { Aktív tehetõs } \\
\text { Aktív nyugdíjas } \\
\text { Otthonülő } \\
\text { Nehéz helyzetú } \\
\text { Rossz egészségi állapotú }\end{array}$ & Jövedelem, társadalmi státus & Bartos, 1980 \\
\hline $\begin{array}{l}\text { Apatikus (érdektelen vásárló) } \\
\text { Gazdaságos (jó ár-érték arány) } \\
\text { Társadalmi/aktív (aktív élet, élvezi a vásárlást) }\end{array}$ & Vásárlói orientáció & Lumpkin, 1985 \\
\hline
\end{tabular}

sen keresnek fel új kiskereskedelmi egységet. A vásárlás során a fiziológiai dimenzió is fontos, különösen, ha várakozásra kerül sor. Az idôsebb fogyasztók akkor fogják magukat jól érezni, ha a vásárlási környezet kényelmes, és ha várakozni kell, leülhetnek.

A vásárlás mögött különféle motivációk húzódnak meg (Bauer - Berács - Kenesei, 2007). Nem csak a termékek megszerzéséról van szó, a vásárlás személyes és társadalmi szükségletek kielégítését is szolgálhatja. A fogyasztói magatartás szakirodalma a következô motivációs tényezóket említi (Blackwell, 2001): másokkal való kommunikáció, tapasztalatszerzés, státus kifejezése, alkudozás/jó vétel öröme, hasunló emberek társasága, önjutalmazás, tanulás új dolgokról, fizikai aktivitás, szórakozás, szerepjátszás stb. Az idôs fogyasztók számára a vásárlás gyakran a vásárlási folyamat élvezetét jelenti, a beszélgetést, az „emberek között lenni” érzését adja (Törôcsik, 2003).

A vásárlási aktivitás is változik az életkorral. Ennek nemcsak anyagi okai vannak, hanem az életkor növekedésével nố azok aránya, akik úgy érzik, hogy már nincs is szükségük egyes termékekre vagy szolgáltatásokra (S. Molnár, 2004).
A reklámokhoz való viszonyt alapvetôen meghatározza, hogyan fogadja és dolgozza fel az információkat a fogyasztó. Az életkorral az emberi szervezetben olyan biológiai változások mennek végbe (látás, hallás, memória), amelyek az ingerek érzékelését, észlelését, és az információk tárolását jelentôsen befolyásolhatják. A 2. táblázatban összefoglaljuk az életkorral összefüggố változásokat az észlelésben és a kognitív képességekben (Rousseau - Lamson - Rogers, 1998: 647. old.; Roedder, 1986) (2. táblázat).

Hogyan kell tehát kommunikálni az idôs fogyasztókkal? - A tanulási folyamat és az üzenct tudatosulásának támogatására vonzó/szakértố típusú kommunikátorokat kell alkalmazni, és növelni kell az ismétlések számát.

- A nyomtatott sajtóban viszonylag nagyméretú betútípust kell alkalmazni, olyan színkombinációkat kell választani, amelyek maximális kontrasztot teremtenek (a kontrasztérzékelési képesség csökkenésének kompenzálására).

- A reklámokban nem célszerú ugyanannak a színnek a közeli ámyalatait alkalmazni, és kerülni kell a zöld- 


\section{Az életkorral összefüggó változások}

\begin{tabular}{|l|l|}
\hline \multicolumn{1}{|c|}{ Képesség } & \multicolumn{1}{c|}{ Életkorral összefuiggó változás } \\
\hline Színlátás & Bizonyos hullámhosszak közötti különbségtétel nehéz (pl. lila, kék és zöld ámyalatok) \\
\hline Kontrasztérzékenység & Szöveg és háttér megkülönböztetése nehezebb, tömörített betúk felismerése probléma lehet \\
\hline Látásélesség & A látás élessége romlik, túl apró betúk felismerése nehéz \\
\hline Vizuális keresés & Vizuális áttekintéssel a releváns információk szelektálása nehéz \\
\hline Hallásfrekvencia-terjedelem & $\begin{array}{l}\text { A magas frekvenciákra való érzékenység csökken, hangok közötti különbségtétel } \\
\text { nehezebb, beszéd és háttérzaj elkülönítése nehezebb }\end{array}$ \\
\hline Rövid távú memória múködésese & $\begin{array}{l}\text { Csökken annak a képessége, hogy az információt aktívan tartsuk a rövid távú } \\
\text { memóriában }\end{array}$ \\
\hline Memóriakapacitás & Lassabb az információfeldolgozás \\
\hline Dekódolás & $\begin{array}{l}\text { Kevésbé jellemzó a szemantikus dekódolás, a vizuális képzelóeró } \\
\text { (az emlékezés mérésénél gyengébb eredmények születnek) }\end{array}$ \\
\hline Információk elôhívása & Gyakran nem hatékony az információk elốkeresése \\
\hline Nyelv megértése & Csökken a nehéz szöveg megértésének képessége \\
\hline Emlékezóképesség & $\begin{array}{l}\text { Némi csökkenés az emlékezốképességben (arra vonatkozóan, hogy milyen teendốket } \\
\text { kell elvégezni a jövốben) }\end{array}$ \\
\hline Szimbólumok értelmezése & A szimbólumokat nehezebb értelmezni \\
\hline
\end{tabular}

kék-lila színárnyalatokat. Ezzel szemben pirosat, sárgát, narancssárgát báran lehet használni.

- A brosúrákban nem szerencsés a magas fényú papírok alkalmazása, mert gátolhatja a pontos érzékelést és a megértést.

- A televízió- és rádióreklámok hosszának meghatározására is oda kell figyelni. A rövid 15 másodperces szpotok egymást követố sugárzása nem megfelelő ennek a célcsoportnak. A szpotok hosszának növelése 30 másodpercról 60 másodpercre vagy 15 másodpercról 30 másodpercre jelentősen javíthatja a megértést.

- A televíziós hirdetésekben az eróteljes háttérzaj vagy aláfestớ zene megzavarhatja az idósebb fogyasztókat az üzenet megértésében.

- Törekedni kell a saját ütemezésú média alkalmazására. Az idósebb emberek számára a nyomtatott sajtónak a legfóbb elónye a televízióval szemben, hogy saját maguk döntik el, milyen tempóban haladnak az információk befogadásával.

- Az irreleváns információk arányát a minimálisra kell csökkenteni, az üzenetet egyszerú, könnyen megérthetô szerkezetben kell bemutatni.

- Ne használjunk diszkriminációt, negatív asszociációkat kiváltó elnevezéseket megszólításukra.

- Olyan témákat vessünk fel a velük történó kommunikációban, ami megszólítja ốket. Ilyenek lehetnek: az egészséggel kapcsolatos témák, a fittség, a jó közérzet, életöröm, derú, a családot középpontba helyezó képek, a fiatalkorhoz tartozó emlékek (zene, személyiségek), a kényelem, puhaság, praktikum bemutatása.

A szakirodalmi áttekintésból a következó fontosabb következtetéseket vonhatjuk le. A születéskor várható élettartam növekedésével, az idős korú népesség aránya növekvő́ tendenciát mutat, ezért a legtöbb tömegtermék és szolgáltatás piacán egyre nagyobb arányban fognak megjelenni az idósebb fogyasztók.

Noha a fiatalság kultusza jellemzi a világot, így Magyarországot is, az idősebb fogyasztók egy jelentős részének lenne igénye és megfelelő vásárlóereje is, hogy új termékeket és szolgáltatásokat próbáljon ki. Küilönösen a technológiai újdonságok elfogadtatásában van nagy szerepe az érintett vállalatok marketingtevékenységének. A szakirodalmi eredmények jelzik, hogy az idősebb fogyasztóknak éppen akkora szüksége lehet például az internetre, mint a fiataloknak, de az ezzel kapcsolatos információfeldolgozás és tanulási folyamat másként megy végbe.

A termékek és szolgáltatások fejlesztésénél is figyelembe kell venni az idősebb fogyasztók igényeit. A vállalatoknak minél több piackutatást kell végezniük az idósebb fogyasztók körében, amellyel feltárhatják, hogy egy adott termékkel vagy szolgáltatással kapcsolatban milyen elvárásaik vannak. Olyan termékeket és szolgáltatásokat kell kínálni számukra, amelyek használata kényelmes, a speciális (pl. egészségügyi) elvárásaiknak jobban megfelel. 
Az 50-en túli fogyasztókról nem szabad sztereotip módon gondolkodni: azaz azt feltételezni, hogy nincs sem igényük termék és szolgáltatások vásárlására, sem vásárlóerejük. Ez a csoport is - a társadalom más csoportjaihoz hasonlóan - összetett mind társadalmi rétegződését, mind életstílusát tekintve. Már ma is van egy jelentős réteg, amely kellő vásárlóerővel rendelkezik. A felsó osztály, a kultúraorientált középosztály és a felhalmozó középosztály aránya egy hazai kutatás (Bukodi, 2004) szerint 22\%, ezek a csoportok minden bizonnyal számos termék és szolgáltatás számára releváns célcsoportnak számítanak, és arányuk feltehetớen növekedni fog a jövőben. A vállalatoknak ezekre a változásokra minél hamarabb fel kell készülniük, és marketingstratégiájukat ebben az irányban tovább kell fejleszteniük.

\section{Kutatási módszertan}

A nemzetközi szakirodalomra támaszkodva kérdőíves megkérdezést végeztünk 2006 novemberében. Alapsokaság az 50. életévüket betöltött, fogyasztói aktivitással $^{5}$ jellemezhető Magyarországon élő́k.

A kérdezóbiztosok a Budapesti Corvinus Egyetem hallgatói voltak, akik rendelkeznek piackutatási tapasztalattal. A mintaelemszám 600 fô, a mintavételi eljárás kvótás mintavétel, amelyben a kvóták az életkor (50-64, és 65-), valamint a nem. A minta nem és életkorcsoportok szerint reprezentálja az 50 éven felüli magyar népességet (3. táblázat).

3. táblázat

\section{A minta megoszlása}

nem és életkorcsoport szerint

\begin{tabular}{|c|c|c|c|}
\hline & Férfi & Nõ & Összes \\
\hline $50-64$ év & 140 & 182 & 322 \\
\hline & $43,5 \%$ & $56,5 \%$ & $100,0 \%$ \\
\hline & $56,2 \%$ & $51,9 \%$ & $53,7 \%$ \\
\hline 65 ev felett & 109 & 169 & 278 \\
\hline & $39,2 \%$ & $60,8 \%$ & $100,0 \%$ \\
\hline & $43,8 \%$ & $48,1 \%$ & $46,3 \%$ \\
\hline & 249 & 351 & 600 \\
\hline & $41,5 \%$ & $58,5 \%$ & $100,0 \%$ \\
\hline Összes & $100,0 \%$ & $100,0 \%$ & $100,0 \%$ \\
\hline
\end{tabular}

A legfiatalabb válaszadó 50 éves, a legidősebb 93 éves (átlag: 63,4, szórás: 10,14).

Cikkünkben jellemezzük e célcsoportot, kiemelten foglalkozunk a vásárlási stílussal, a nosztalgiaérzéssel, az értékekkel, a szabadidő́s tevékenységekkel, valamint a reklámmal szembeni attitưdökkel.

\section{Termékek és szolgáltatások vásárlása}

A megkérdezettek az elmúlt két évben számos terméket és szolgáltatást vásároltak, illetve kaptak ajándékba. Legnagyobb arányban a lakberendezést, háztartási gép vásárlását, a lakásfelújítást és mobiltelefon vásárlását említettek az elmúlt két év nagyobb értékú (tízezer forintot meghaladó) kiadásai között. Meglepóen alacsony azok aránya, akik ajándékba kaptak a fentiek közül termékeket és szolgáltatásokat. Bár nem túl magas arányban, de mégis a legjellemzóbb a mobiltelefon, háztartási gép, DVD és az ékszer ajándékozása. Noha a lista nem teljes, az alacsony értékek utalhatnak arra, hogy az 50-en túliakat nem tudják ily módon támogatni a fiatalok, vagy ezt nem tartják fontosnak.

A demográfiai ismérvek közül az életkor, a mobiltelefon és a háztartási gép vásárlása között találtunk szignifikáns összefüggést. A 65 év és afeletti korosztály a többieknél nagyobb arányban $(51,2 \%)$ vásárolt háztartási gépet, az 50-64 évesek pedig nagyobb arányban $(63,7 \%)$ vettek mobiltelefont, mint az idősebbek. A mobiltelefon vásárlása a Budapesten és a megyeszékhelyeken élókre is jobban jellemző (64,7\%, illetve $61,8 \%)$.

A vásárlási stílus mérésére a Sproles és Kendall (1986), illetve a Sproles és Sproles (1990) által kifejlesztett mérőskálát használtuk. Ez a skála ötvözi a döntéshozatali stílus számos jellemzôjét, beleértve a vásárlás fontosságát, a minőség, az ár és a márkák szerepét.

Eredményeink szerint a megkérdezettek erősen minöségorientáltak, megfontolt gondolkodásmóddal jellemezhetőek, és ragaszkodnak a jól bevált dolgokhoz. Leginkább a következő állításokkal értenek egyet (1=egyáltalán nem ért egyet, $5=$ teljes mértékben egyetért):

1. Próbálok kedvezó árért jó minőségư terméket venni. $(4,5)$

2. Ha egy termék bevált, ragaszkodom hozzá. $(4,4)$

3. Mindig jó minőségú terméket próbálok vásárolni. $(4,3)$

4. Magas elvárásokat támasztok az általam vásárolt termékekkel szemben. $(4,1)$

5. Szánok idốt arra, hogy jó döntést hozzak. $(4,0)$ Legkevésbé pedig a divat tûnik fontosnak, és a reklámmal szemben is inkább szkeptikusnak tưnnek a megkérdezettek. A legkevésbé jellemzó állítások a következók:

1. A divatos stílus fontos a számomra. $(2,1)$

2. A vásárlásaimmal követem az aktuális divatot. $(2,2)$

3. A legtöbbet reklámozott termék általában jó választás. $(2,2)$

4. Gyakran megesik, hogy meggondolatlanul vásárolok. $(2,2)$

5. A vásárlás kimondottam kellemetlen számomra. $(2,3)$ 
A vásárlási stílust méró 32 változó redukálásával megkaphatjuk a döntéshozatalt jellemzó fóbb dimenziókat. Az alkalmazott elemzési módszer a faktoranalízis ${ }^{6}$, az egyes faktorok a 4. táblázat szerint jellemezhetók:

\section{Döntéshozatalt jellemzô fớbb dimenziók}

4. táblázat

\begin{tabular}{|l|l|}
\hline 1. faktor & Minơségorientáció \\
\hline 2. faktor & Változatosság keresés \\
\hline 3. faktor & Negatív attitưd a vásárláshoz \\
\hline 4. faktor & Árérzékenység \\
\hline 5. faktor & Bizonytalanság \\
\hline 6. faktor & Alacsony érdekeltség \\
\hline 7. faktor & Megfontoltság \\
\hline 8. faktor & Lojalitás \\
\hline 9. faktor & Külsó fogodzók alkalmazása (ár, reklám) \\
\hline
\end{tabular}

A fenti dimenziók alapján fogyasztói csoportokat képeztünk ${ }^{7}$ (5. táblázat).
Az egyes csoportok mintabeli megoszlása kiegyensúlyozott, a negatív attitưddel bírók némi túlsúlya mellett. Megvizsgáltuk azt is, hogy demográfiai ismérvek szerint különböznek-e az egyes csoportok. A nem, lakhely, életkor, anyagi helyzet szerint nem találtunk szignifikáns különbségeket. Az iskolai végzettségben azonban vannak számottevố eltérések. A vásárláshoz negatívan viszonyulók között nagyobb arányban vannak a felsőfokú végzettségúek, a változatosságkeresók között a szakmunkás-bizonyítvánnyal rendelkezők, az alacsony érdekeltségúek között a nyolc általánossal vagy szakmunkás-bizonyítvánnyal rendelkezók, a mérlegelők között pedig az érettségizettek.

\section{A nosztalgia érzése}

A vizsgált korosztály fogyasztói magatartását meghatározó tényezók közül érdekes szerepe van a nosztalgia jelenségének. A nosztalgiaérzés arra utal, hogy az ember visszavágyik a múltba, és olyan tevékenységet

Fogyasztói csoportok

\begin{tabular}{|c|c|}
\hline A klaszter neve & Jellemzese \\
\hline 1. Változatosság keresô & $\begin{array}{l}\text { Szeret új termékeket kipróbálni, figyel a divatra, keresi a külsõ fogodzókat, } \\
\text { a reklámból és árakból is igyekszik következtetéseket levonni. }\end{array}$ \\
\hline 2. A vásárláshoz negatívan viszonyuló & $\begin{array}{l}\text { A fớ megkülönböztetố vonása, hogy a vásárlást kellemetlenek, idópocsékolásnak érzi. } \\
\text { Ha vásárol, az átlagosnál valamivel megfontoltabb, és igyekszik ugyanazokat a márkákat } \\
\text { venni, ugyanabba a boltba menni. }\end{array}$ \\
\hline 3. Alacsony érdekeltségư & $\begin{array}{l}\text { Ez a típusú fogyasztó nem törớdik sokat a vásárlásaival, nem tépelődik a döntés elớtt, } \\
\text { nem keresi a változatosságot, nem figyel a külsó jelzésekre (ár vagy reklám), ha teheti, } \\
\text { ugyanazt a márkát veszi, feltehetôleg praktikus szempontok miatt. } \\
\text { Valamivel kisebb árérzékenység jellemzi, mint a többieket. }\end{array}$ \\
\hline 4. Mérlegelő & $\begin{array}{l}\text { Nem dönt elhamarkodottan, igyekszik kedvezô árért jó minớséget venni. } \\
\text { Ennek feltehetớen utána is jár, mert a lojalitás nem jellemzó rá. A vásárlás szórakoztatja. }\end{array}$ \\
\hline
\end{tabular}

Minőségorientációban nincsenek jelentơs különbségek a csoportok között, feltehető́en azért, mert a minőség mindenki számára viszonylag fontos, amint az egyes szempontokra adott átlagértékekból is kiderült ( 1 abra).

1. abra

\section{A vásárlásistílus-csoportok megoszlása}

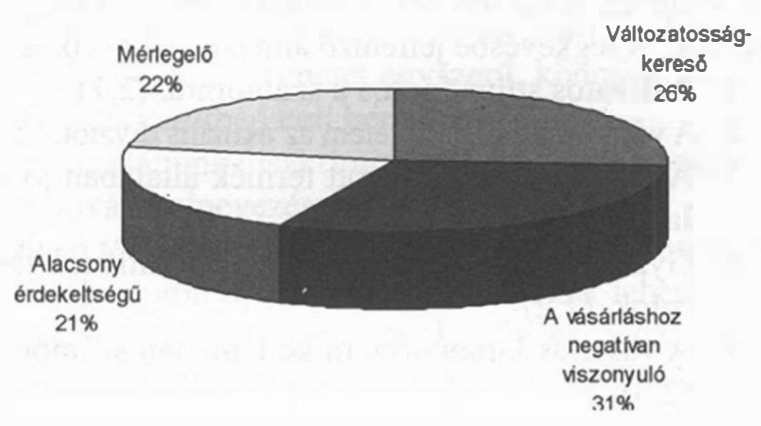

vagy tárgyakat preferál, amelyek akkor voltak népszeríek, amikor még fiatal volt (Holbrook, 1993).

Kutatásunkban a nosztalgiaérzést a következó állításokkal mértük (átlagértékek):

1. A régi szép időkben jobb volt az élet. $(3,42)$

2. A technikai változás szebb jövớt hoz az embereknek. $(3,41)$

3. Az élet minősége folyamatosan romlik. $(3,35)^{8}$ Megállapíthatjuk, hogy a nosztalgia érzése a közepesnél erósebb mértékben jellemzó a megkérdezettekre (nosztalgiaskála átlaga: 6,77, szórása: 2,42, terjedelem, 2-10).

A demográfiai változók hatásáról megállapíthatjuk, hogy a nem és az életkor nem befolyásolja a nosztalgiaérzést. Ez utóbbi ellentétes várakozásainkkal, hiszen feltételezni lehetett, hogy az életkor előrehaladtával az 
emberek idegenül érezhetik magukat a mai világban és inkább visszavágynak a múltba. Úgy tünik azonban, hogy az ötvenen túliak ebból a szempontból inkább homogének. A vásárlásistílus-csoportok közül nem meglepó módon a vásárláshoz negatívan viszonyulók körében erósebb a nosztalgiaérzés, ami egy magyarázata lehet kedvezớtlen hozzáállásuknak: feltehetóen úgy érzik, hogy a múltban általában jobban lehetett boldogulni.

A legmagasabb iskolai végzettség hatása egyértelmú: a végzettség csökkenésével nó a nosztalgiaérzés. Úgy tưnik, hogy a magasabb végzettség olyan készségeket ad az emberek kezébe, amelyek révén jobban tudnak alkalmazkodni a megújulo körülményekhez, és kevésbé vágynak vissza a múltba.

A jövedelmi helyzet megítélése is szignifikáns kapcsolatban áll a nosztalgiaérzéssel. Azok, akik úgy érzik, hogy az átlagnál kevesebb a jövedelmük, vagy az anyagi helyzetük romlott az elmúlt öt évben, magasabb értékeket értek el a nosztalgiaskálán.

\section{Értékek}

Cikkünk harmadik központi kérdése az értékekkel foglalkozik. Az értékek mérésére számos módszertan áll rendelkezésres. Az egyik legismertebb módszer

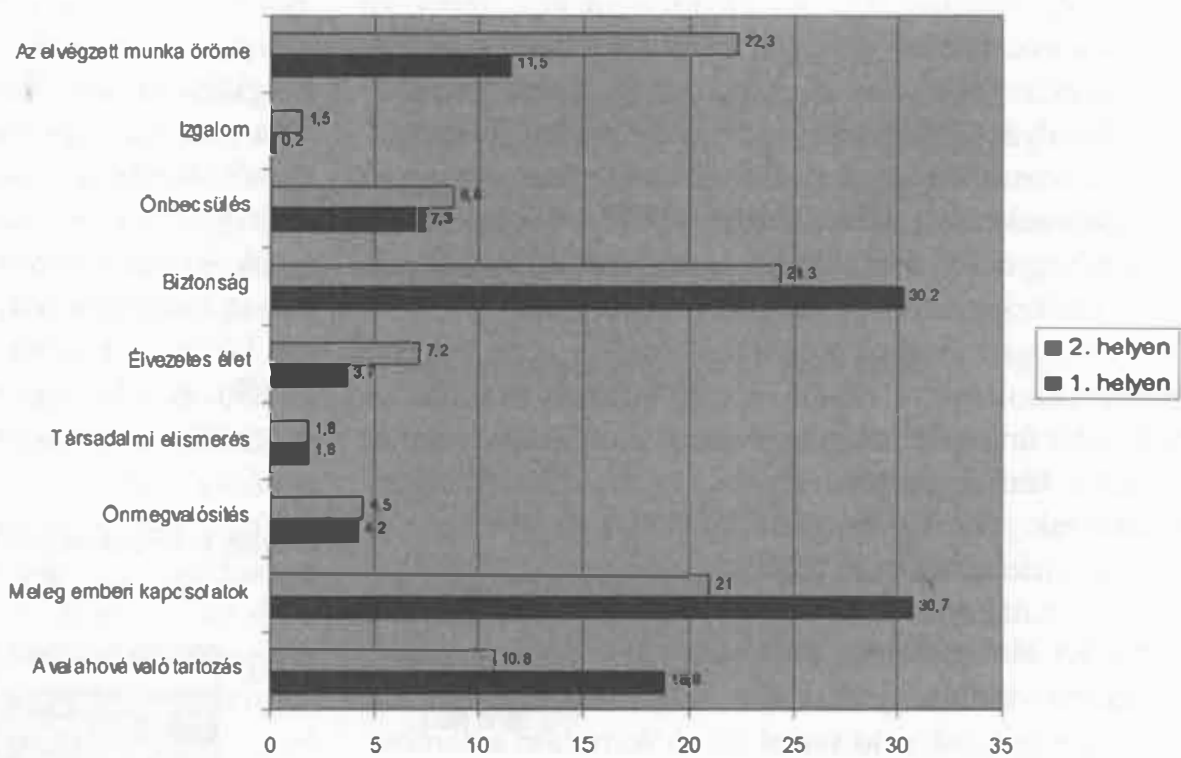

Rokeach értékmérő rendszere, amely két különbözó értékkészletet tartalmaz: cél- és eszközértékeket (Rokeach, 1968). A Rokeach-mérés bonyolult alkalmazhatósága miatt Kahle (1983) kifejlesztett egy kilenc elemból álló értéklistát (LOV), amely jobban alkalmazhàtó különbözó hátterú megkérdezettek esetében is. Kérdóíves megkérdezésünk során a LOV-listát alkalmaztuk, amelyból a megkérdezettek kiválasztották a számukra legfontosabb két értéket (2. ábra).

Látliató, hogy a legfontosabb értékek (a megkérdezettek legnagyobb arányban ezeket választották elsó helyen) a meleg emberi kapcsolatok és a biztonság. Az izgalom, a társadalmi elismerés, az önmegvalósítás és az élvezetes élet csak a megkérdezettek töredékének

Értékek és a válaszadó életkora és neme közötti kapesolat (n=6000,\%)

\begin{tabular}{|l|c|c|c|c|c|}
\hline & \multicolumn{2}{|c|}{ Nem } & \multicolumn{2}{c|}{ Életkor } & Minta \\
\hline Érték & Férfí & Nó & $50-64$ év & 65 év felett & \\
\hline A valahová való tartozás érzése & 26,5 & $31,9^{*}$ & 26,4 & $33,5^{*}$ & 29,7 \\
\hline Meleg emberi kapcsolatok & 42,2 & $58,4^{*}$ & 54,0 & 48,9 & 51,7 \\
\hline Önmegualósítás & $11,6^{*}$ & 6,6 & $12,1^{*}$ & 4,7 & 8,7 \\
\hline Társadalmi elismerés & 5,0 & 4,8 & 5,0 & 7,2 & 6,0 \\
\hline Élvezetes élet & $14,1^{*}$ & 8,5 & $13,4^{*}$ & 7,9 & 10,8 \\
\hline Biztonság & 54,2 & 54,7 & 55,0 & 54,0 & 54,5 \\
\hline Önbecsülés & 15,3 & 16,8 & 17,4 & 14,7 & 16,2 \\
\hline Izgalom & 2,4 & 1,1 & 2,5 & 0,7 & 1,7 \\
\hline Az elvégzett munka öröme & 39,4 & 29,9 & 33,2 & 34,5 & 33,8 \\
\hline
\end{tabular}


számít fontosnak. Úgy túnik tehát, hogy a megkérdezettek a hagyományos értékeket részesítik elő́nyben, a hedonista beállítottság, versenyszellem nem jellemzó erre a korosztályra.

Megvizsgáltuk azt is, hogy az értékeket mennyiben befolyásolják a válaszadó demográfiai jellemzói. Legmarkánsabb hatása a nemnek és életkornak van, az eredményeket a 6. táblázat tünteti fel. A könnyebb kezelhetôsé́g érdekében az elsó és a második helyen említett értékekre adott válaszokat összevontuk.

A vizsgált értékek közül jellemzóen a meleg emberi kapcsolatok, a valahová való tartozás számítanak nớiesebb értéknek, míg az önmegvalósítást, élvezetes életet a férfiak tartják fontosabbnak. Az egyes életkorcsoportok között is több eltérést találtunk. Az idósebb, 65 év és afeletti korosztályra jobban jellemzó érték a valahová való tartozás, míg a fiatalabb ötvenen túliaknál az önmegvalósítás és az élvezetes élet tứnik jellemzőbbnek.

Más demográfiai ismérvek hatásáról a következóket állapíthatjuk meg. A felsőfokú végzettséggel rendelkező́k szignifikánsan nagyobb arányban említették $(14,8 \%)$ az önmegvalósítást az első́ és második helyen. Az élvezetes élet mint érték a nemen és életkoron kívül az anyagi helyzettel, illetve annak változásával is összefügg. Az átlagon felüli jövedelmúek $(22,9 \%)$ és a javuló anyagi körülmények között élók $(17,1 \%)$ számára elő́kelő helyen szerepelt e hedonista értékorientáció. Úgy tünik, hogy a maslow-i szükséglethierarchia elvei jól magyarázzák e korosztály értékorientációit. Ezen elvek szerint ugyanis az emberek elöször alacsonyabb szintư (éhség, szomjúság, alvás stb.) szükségleteiket elégítik ki, és ha ezek teljesülnek, akkor foglalkoznak a hierarchiában magasabb helyet elfoglaló szükségleteik kielégítésével (biztonság, valahová való tartozás, elismerés, önmegvalósítás).

A vásárlási stílus alapján képzett csoportoknál egy érték tekintetében találtunk szignifikáns különbségeket: a változatosságot keresốk számára az izgalom nagyobb arányban merült fel, mint fontos érték (4,4/\%).

\section{Szabadidős tevékenység}

Kutatásunkban azt is vizsgáltuk, hogy milyen gyakorisággal folytatnak egyes szabadidős tevékenységet a megkérdezettek. Rákérdeztünk a TV-nézési szokásaikra, napilap- és magazinolvasásra, könyvolvasásra, rádióhallgatásra, internetezésre és az otthonon kívüli szórakozásra. A 3. ábra tünteti fel az eredményeket.

A leggyakrabban végzett tevékenységek a TV nézés (a megkérdezettek 68\%-a gyakran néz televíziót), ezt követi a napilapolvasás (64\%) és a rádióhallgatás (59\%). A soha nem végzett tevékenységek között legnagyobb arányban az internetezés és az otthonon kívüli

3. ábra
Szabadidős tevékenységek gyakorisága $(\mathrm{n}=600, \%)$

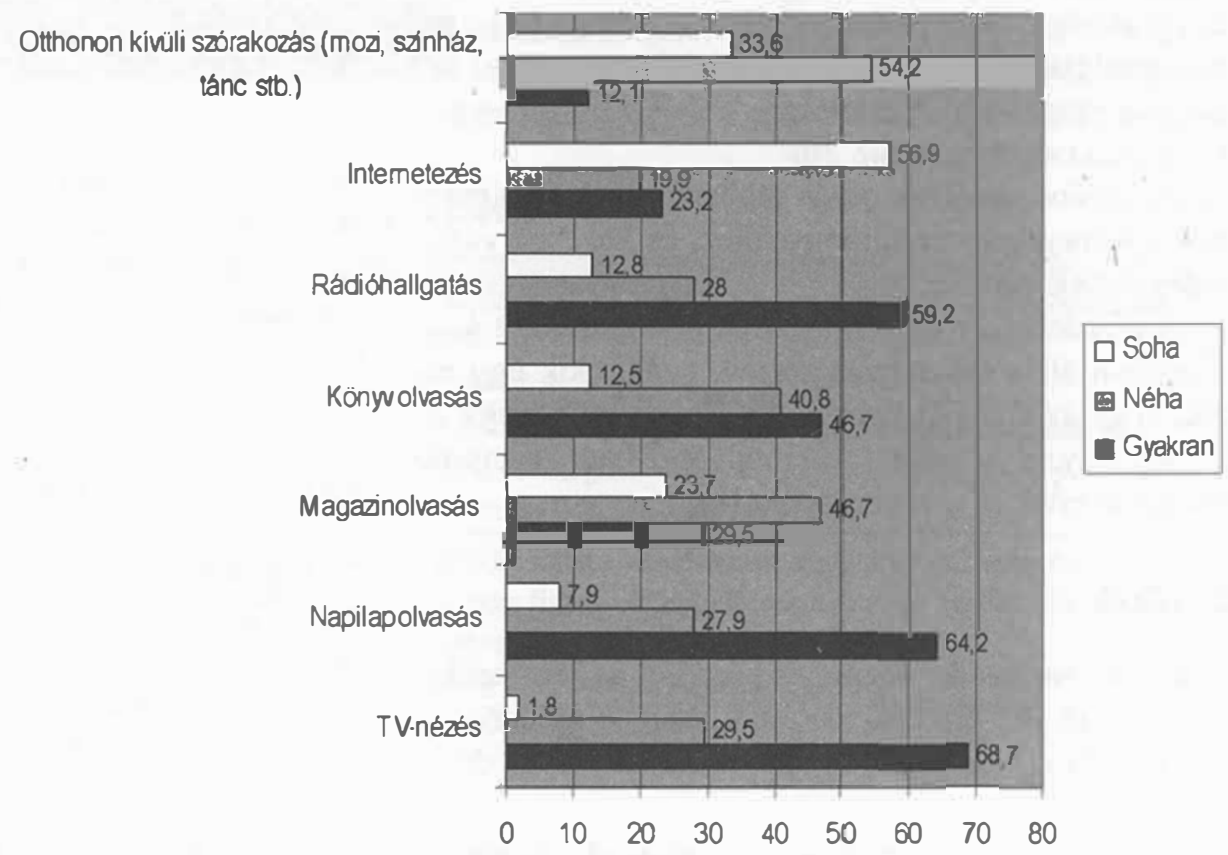

szórakozás szerepel, ugyanakkor a gyakorisági megoszlások azt mutatják, hogy mind az internet, mind pedig az otthonon kívül szórakozás a megkérdezettek egy jelentốs részére kisebb gyakorisággal ugyan, de jellemzó. Sớt az internetezés terén a megkérdezettek 23\%-a jelezte, hogy gyakran ül a gép elé. Az otthonon kívüli szórakozásról is elmondhatjuk, hogy a megkérdezettek több mint fele idônként eljár szórakozni.

A demográfiai változók hatásáról a következóket emeljük ki. A gyakori TV-nézés inkább a 65 év és afeletti korcsoportra jellemzó, akik viszonylag alacsonyabb végzettségúek. Napilapot gyakrabban olvasnak az érettségivel vagy felső́fokú végzettséggel rendelkezók és a megyeszékhelyeken élők. A magazinolvasás 
gyakoribb tevékenység a változatosságot kereső és a mérlegeló vásárlási stílussal jellemezhetőek körében, továbbá a nók és az érettségizettek között. A 65 év és afeletti korosztályra az átlagosnál jobban jellemző, hogy soha nem olvas magazint. A könyv a mérlegeló vásárlási stílussal jellemezhető emberek gyakori időtöltése. Jobban jellemzó e tevékenység továbbá a felsơfokú végzettségứekre és a Budapesten élókre. A gyakori rádióhallgatás jobban jellemzó az érettségivel vagy felsőfokú végzettséggel rendelkezókre és Budapesten vagy a megyeszékhelyeken élókre.

$\mathrm{Az}$ internethasználat gyakoriságában az 50-65 év közötti korcsoport vezet. Számottevő a különbség a két életcsoport között $(37,7 \%$ vs. $10,1 \%$ a gyakran internetező́k aránya). A felsőfokú végzettség segíti a számítástechnikai ismeretek könnyebb elsajátítását, a hozzáférés különbségeit jelzi, hogy Budapesten és a megyeszékhelyeken nagyobb a gyakran internetezók aránya. Végül, míg más tevékenységekre az észlelt jövedelmi helyzet nincs hatással, ebben az esetben mind az átlagon felüli jövedelemmel bírokra, mind pedig a javuló anyagi körülmények között élőkre jobban jellemzô a gyakori internetezés.

Az otthonon kívüli tevékenységek esetében a 65 év és az afelettiekre, valamint a községben élókre az átlagosnál jobban jellemző, hogy soha nem mennek el szórakozni. A felsőfokú végzettségứek nagyobb arányban jámak gyakran szórakozni. Az átlagon felüli jövedelemmel rendelkezókre az alkalmankénti szórakozás jellemzó leginkább.

Az ötvenen túliakat érdeklő témákat maguk a megkérdezettek vetették fel. Legnagyobb arányban $(51 \%$ uk) a politikát és az egészséget $(48 \%)$ említették. Ezt követik a családi kapcsolatok $(47 \%)$ és a kultúra (40\%). A megkérdezettek közel egyharmadát érdekli a gazdaság, a filmek, a kertészkedés és a rejtvények (4. ábra).

Megnéztük azt is, hogy az egyes demográfiai változók alapján képzett csoportokban hogyan alakulnak a témapreferenciák. A legerósebb differenciálo ismérv a válaszadó neme: a vizsgált 15 téma közül 12 estében voltak szignifikáns különbségek nók és férfiak között. További fontos ismérv az iskolai végzettség is.

Összefoglalóan megállapíthatjuk, hogy az 50-64 év közöttiek nagyobb arányban említették a gazdaságot, a kultúrát, a filmet, a lakberendezést és a technikát, mint számukra érdekes témákat. A férfiak a következó témák iránt érdeklődnek jobban: gazdaság, politika, külföld, barkácsolás, technika. Nói témának számít a kultúra, egészség, család, gyerek, sütés, hírességek, lakberendezés. A felsớfokú végzettségứek a többieknél jobban preferált témái a gazdaság, a kultúra és a technika. $\mathrm{Az}$ alacsonyabb iskolai végzettségúek a többieknél nagyobb arányban érdeklődnek a barkácsolás iránt. A középfokú végzettségúek pedig jellemzóen a kertészkedéshez és a lakberendezéshez kötődnek jobban.

\section{A reklámmal szembeni attitúdök}

A válaszadóktól először egy nyílt kérdés formájában megkérdeztük, hogy mit gondolnak a reklámokról. A vélekedések döntố többsége, $67 \%$-a negatív töltetũ volt. A reklámok elutasításánál a gyakran felmerüló indokok között szerepel, hogy a reklámok „unalmasak”, „,idegesítőek”, „félrevezetőek”, „tolakod6ak”, „,bugyuták", és nem kevesen mondták, hogy nem tudják, miról szólnak a reklámok és túl hangosak, ráadásul túl sok is van belólük.

A válaszadók mindössze $6 \%$-ának volt határozott pozitív véleménye. Ó́k legtöbbször a reklám szórakoztató jellegét emelték ki, azt hogy információkat közvetít: „,könnyebb eligazodnia vásárlásnál”, ,informálódok az új termékekról”, ,, segít dönteni a vásárlásnál”, „felhívja a figyelmet az akciós termékekre". Mások tisztában vannak a reklámoknak a gazdaságban betöltött szerepével: „, a marketing fontos része a gazdaságnak”, „a reklám jó idóben, jo helyen lehet eredményes”.

$27 \%$ vagy semleges: „nem befolyásolnak”, vagy pedig látja a reklámok rossz és jo oldalát is: „szórakoztatoak, de kicsit sok van belólük”, „valamennyire hasznos, de sokszor túlzásba esik”, „vannak jo és vannak rossz reklámok".

\section{Preferált témák megoszlása $(\mathrm{n}=600, \%)$}

4. abra

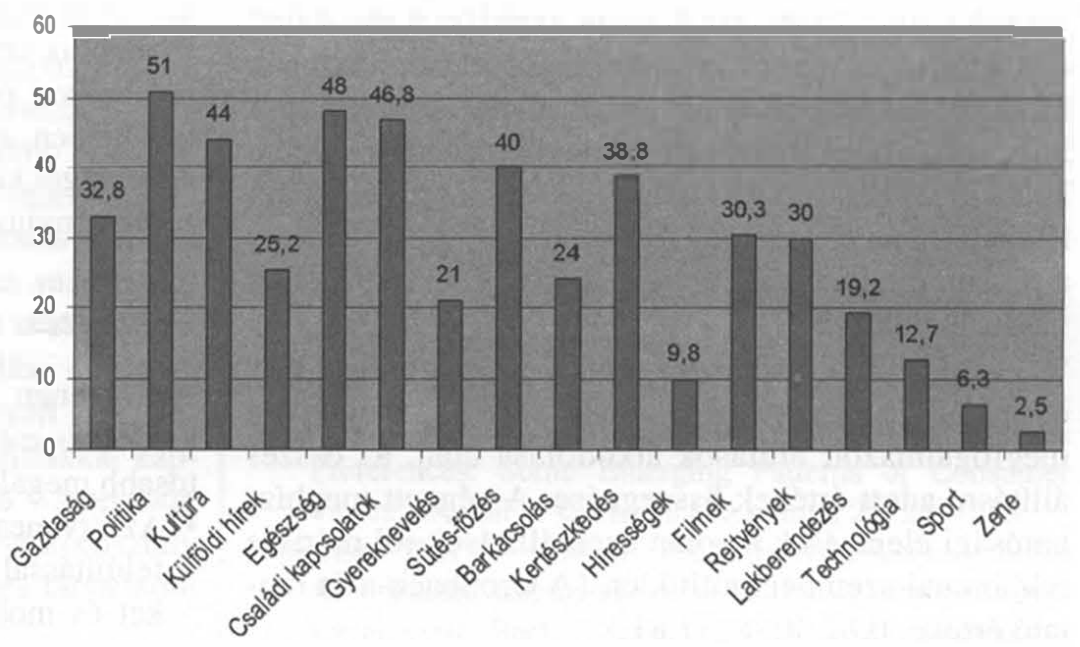


A legtöbb megjegyzés a reklámok kreatív megoldásaira vonatkozott. Gyakran előfordul6 (negatív) vélekedés, hogy a reklámok nem a valóságot mutatják: „a valóságtól messze elrugaszkodott reklámok vannak", „elvétve vannak jol kitalált reklámok". Az érthetôséggel is olykor gondjuk van a megkérdezetteknek: „,sokszor nem tudom, miről szólnak, idegesítenek", vagy „félrevezető az elolvashatatlan apr6 betư". Itt is megjelenik a nosztalgia érzése: „A régebbi reklámok sokszor elfogadhatobbak voltak, mint manapság”.

A negatív attitưdök a kvantitatív mérés esetében is szembetúnóek, amint ezt az 5. ábra is mutatja. A válaszadóktól azt kérdeztük, hogy egy sor reklámmal kapcsolatos állítással egyetértenek-e vagy sem, a mérés ötfokú skálán történt. A skálát Pollay és Mittal (1993) tesztjének felhasználásával alakítottuk ki. A megkérdezettek inkább egyetértenek azzal, hogy a reklám a mai üzleti élet szükséges része $(3,9)$, de inkább manipulatívnak $(3,8)$ és bugyutának $(3,7)$ tartják őket. A reklám pozitív gazdasági hatásairól a megkérdezettek inkább kétkednek: nem igazán gondolják azt, hogy a reklám hozzájárul az életszínvonal emelkedéséhez $(1,8)$ vagy a reklám èredményeként az emberek jobb termékeket vásárolhatnak $(2,4)$.

A reklámmal szembeni attitúd jellemzéséhez egy összegzó indikátort képeztünk, amely a negatívan megfogalmazott állítások átkódolása után, az összes állításra adott értékek összegzése. A végzett megbízhatósági elemzések alapján ezen állítások jól mérik a reklámmal szembeni attitúdöt. (A Cronbach-alfa mutató értéke: 0,82 átlag: 37,81.) S= teljes mértékben egyetért)

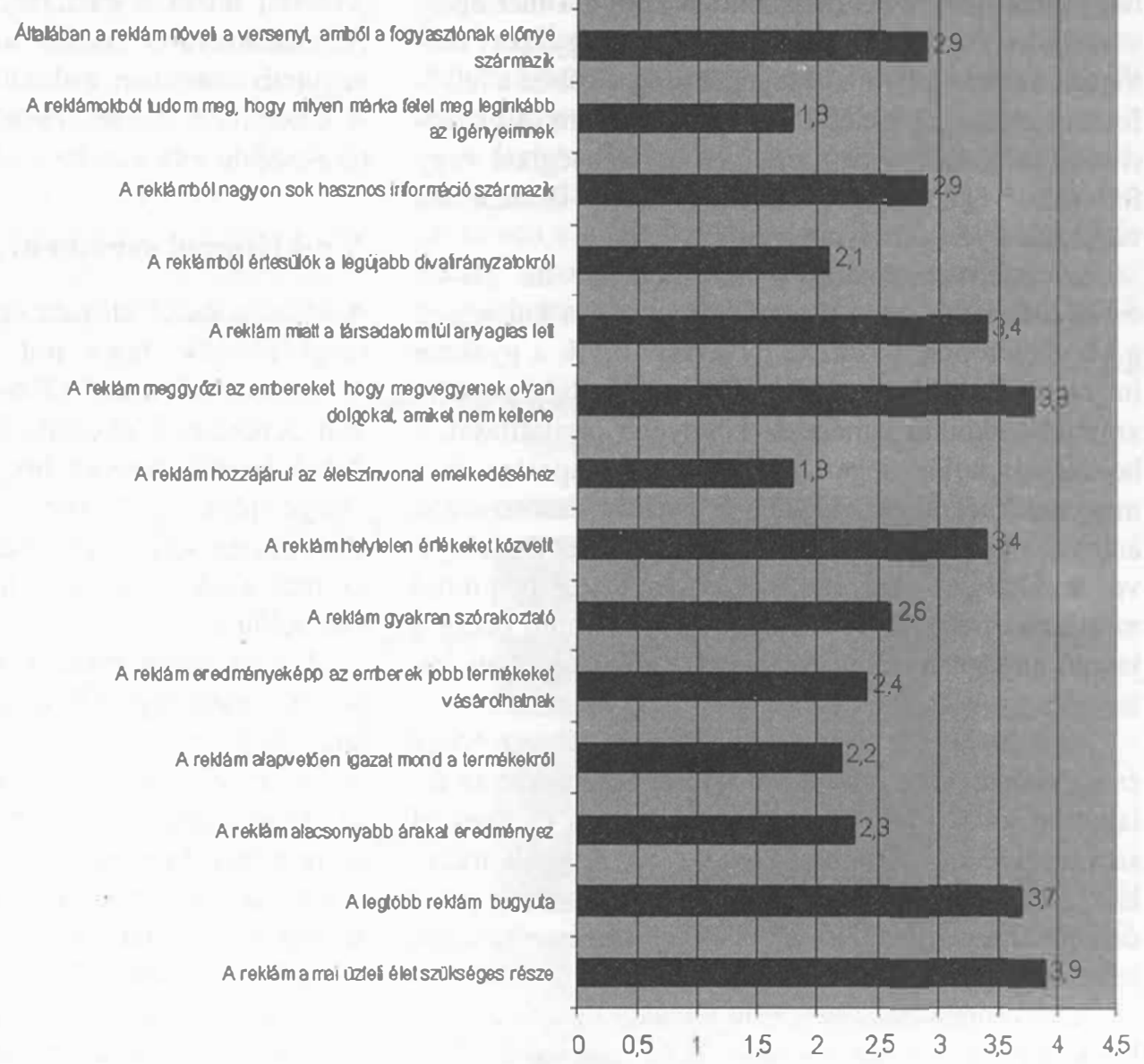

(Az egyes állításoknál az érvényes válaszok száma 545 és 597 között mozog, l= egyáltalán nem ért egyet,

A válaszadó demográfiai jellemzói közül a lak6hely és a jövedelmi helyzet hefolyásolják a reklámmal szembeni attitứdöt. A vidéki városokban élóknek kedvezóbb az attitứdje $(39,8)$, valamint az anyagi helyzet javulásával pozitívabban értékelik a reklámot $(39,8)$, feltehetően a reklámozott termékek elérhetơségének nehézségei kevésbé érintik őket. A sajtótermékre előfizetớk is nyitottabbak a reklámok iránt $(38,7)$.

\section{Összegzés}

$\mathrm{Az}$ ötvenen túliak fogyasztói magatartását vizsgálo kérdőíves megkérdezés elemzéséből a következó fontosabb megállapításokat emeljük ki.

- Az ötvenen túli korosztály lakberendezéssel, lakásfelújítással kapcsolatos termékeket, háztartási gépeket és mobiltelefont vásárol legnagyobb arányban. 
A nagyobb érték termékek ajándékozása nem jellemzó, a megkérdezetteknek csak töredéke kapott ilyen terméket ajándékba.

- Az ötvenen túli fogyasztók vásárlási stílusára a megfontoltság és az értékorientáció jellemzó. Fontos szempont a vásárlásnál az ár-érték arány figyelembevétele, a minőségre való törekvés és a jól bevált megoldásokhoz való ragaszkodás.

- A vásárlási stílusok alapján négy szegmentumba sorolhatók be a megkérdezettek: mérlegelö, változatosságkeresô, alacsony érdekeltségư és a vásárláshoz negatívan viszonyuló. Az első két csoport aránya $48 \%$, óket lehet könnyebben elérni a kommunikációs csatornákon.

- A nosztalgia érzése a közepesnél erósebb mértékben jellemzó erre a korosztályra. Különösen az alacsonyabb iskolai végzettséggel és az átlagosnál kedvező́tlenebb anyagi körülmények között élő́k számára lehet vonzó a nosztalgiaérzésre építő marketingkommunikáció.

- A vizsgált korosztály számára a legfontosabb értékek a meleg emberi kapcsolatok és a biztonság, amelyek mint alapmotivációk befolyásolják vásárlási döntéseiket.

- A leggyakrabban végzett szabadidős tevékenység a TV-nézés és a napilapolvasás, azonban a megkérdezettek számos más szabadidős tevékenységet is folytatnak (a kertészkedéstơl a síelésig, borászatig).

- Tematikus érdeklődésüket tekintve megállapíthato, hogy a legkedveltebb témák a politika, az egészség és a családi kapcsolatok. Jelentős különbség van a nők és a férfiak témapreferenciái között.

- Az internetet a megkérdezettek $44 \%$-a használta már valamilyen célra, ami lényegesen nagyobb a teljes 50 év feletti sokaságra jellemzó értéknél (17\%), ez a magasabb szintư fogyasztói aktivitásukkal is öszszefügg.

- A reklámról alapvetốen negatívan vélekednek a válaszad6́k. Sokan unalmasnak, félrevezetónek és tolakodónak tartják a reklámokat, azonban tudomásul veszik, hogy ez a mai üzleti élet szerves része.

Kutatásunk megerősítette azt az egyre inkább elterjedó felfogást, miszerint az idősebb korosztály marketingjelentősége nő, és számos termék és szolgáltatás számára növekvő célcsoportot jelenthet. A sikeres marketingtevékenységhez azonban elengedhetetlen e célcsoport sajátosságainak ismerete, akár a vásárlási stílusról, akár a reklámüzenetek befogadásárol legyen szó. Abban biztosak lehetünk, hogy az ötvenen túliakkal kapcsolatos - alacsony vásárloerốt feltételezó - sztereotip gondolkodás nem állja meg a helyét; ez a korosztály heterogén, és éppúgy megjeleníti az egyes társadalmi rétegeket, mint a fiatalabb korosztályok.

\section{Lábjegyzet}

1 A kutatás a Sanoma Budapest Zrt. támogatásával valósult meg.

${ }^{2}$ Figyelő, 2004. április 2-28, 47. oldal

3 In: Wealth with Wisdom, Serving the Needs of Aging Consumers, 2005, www.deloitte.com, 7. oldal

+ AARP (American Association of Retired Persons), 2004

s A fogyasztói aktivitás mérésére a következố szârôkérdéseket alkalmaztuk: Milyen terméket/szolgáltatásokat vásárolt Ön vagy az Ön háztartása az elmúlt 2 évben a felsoroltak közül? Ha nem vásárolta, a fentiek közül kapott-e valamit ajándékba?

${ }^{6}$ KMO: 0,789, Bartlett-teszt: khi-négyzet: 4750,48, sig: 0,000, a magyarázott variancia: $60 \%$, módszer: fơkomponens elemzés, rotáció: varimax.

7 Az alkalmazott módszer a klaszteranalízis volt. Elsô lépésben hierarchikus eljárással, a minta véletlen 10\%-ra kétszer elvégzett elemzéssel, a dendrogramok négy klaszteres megoldást mutattak. Ezt követóen k-means eljárással alakították ki a klasztereket.

8 A végzett megbízhatósági vizsgálatok szerint a második állítás (fordított kódolás után) nem illesz.kedik a nosztalgiaskálába, ezért a következố megállapításainknál kêt tételbôl álló nosztalgiaskálát alkalmazunk, amelynek Cronbach-alfa mutatója megfelel a minimálisan elvárt értéknek: értéke 0,6.

9 Magyarországon is több kutatás készült az értékek témakörében, például Hofmeister Tớth Ágnes, Totth Gedeon (2004). Borvásárlási magatartás és értékalapú szegmentáció, in: Marketingelmélet, és gyakorlat, szerk. Berács J. és szt., KJK-Kerszöv., Neulinger Ágnes (2001) Fogyasztói értékek és vásárlói magatartás (2001) Marketing \& Menedzsment, 1., 30-35.

\section{Felhasznált irodalom}

Barak, B. (1987): Cognitive Age; a new multidimensional approach to measuring age identity, International Journal of Ageing and Human Development, Vol. 25, 19-128.

Barak, B. -Marthur, A. - Lee, K. - Zhang, Y. (2001): Perceptions of age identity, a cross-cultural inner age exploration, Psychology and Marketing, Vol. 18, N.10, 1003-29.

Bartos, R. (1980): Over 49: The Invisible Consumer Market, Harvard Business Review, 58, 140-148.

Bauer A. - Berács J. - Kenesei Zs. (2007): Marketing alapismeretek, Aula, Budapest

Blackwell, R. D. - Miniard, P. W. - Engel, J. F. (2001): Consumer Behavior, Harcourt College Publishers

Bone, P.F (1991): Identifying mature segments, The Journal of Consumer Marketing, Vol. 8, N.4, Fall, 19-31.

Bukodi E. (2004): Az idôssek társadalmának rétegzôdése in: Giczi Johanna, Sághi Gábor szerk. Idôskorúak Magyarországon, 2004, KSH, 49-62.

Grey Reklámügynökség (1998): Master Consumer, tárgyalja: Törốcsik Mária, 2003, Fogyasztói magatartás trendek, KJK, Budapest

Holbrook, M. (1993): Nostalgia and Consumption Preferences: Some Emerging Patterns of Consumer Tastes, Journal of Consumer Research, 20, 245-256.

Hofmeister Tóth A. - Totth G. (2004): Borvásárlási magatartás és értékalapú szegmentáció, in: Marketing elmélet és gyakorlat, szerk. Berács J. és szt., KJK-Kerszöv, Budapest

\section{VEZETÉSTUDOMÁNY}




\section{CiKKEK, TANUCMÁNYOK}

Kahle, L. R. (1983): Social Values and Social Change: an Aadaptation to Life in America. Praeger, New York

Keszthelyiné Dr: Rédei M. (2004): Az időskorú háztartások fogyasztási színvonala és szerkezete (A KSH háztartási költségvetési felvételének adatai alapján) in: Giczi Johanna, Sághi Gábor szerk., Időskorúak Magyarországon, KSH, 143-174.

Kramer's Senior Citizen's Marketing Group, tárgyalja: Bone P.F. (1991) Identifying mature segments, The Journal of Consumer Marketing, vol. 8, N. 4., 26-27.

Lumpkin, J. R. (1985): Shopping Orientation Segmentation of the Elderly Consumer, Journal of the Academy of Marketing Science, Spring, Vol. 12. N. 2, 271-289.

Neugarten, B. L. (1982): Policy for the 1980's: Age or Need Entitlement? In: Aging: Agenda for the Eighties, National Journal Issues Book, 19-32.

Neulinger A. (2001): Fogyasztói értékek és vásárlói magatartás. Marketing \& Menedzsment, 1., 30-35.

Pollay, R. W. - Mittal, B.(1993): „Here's the Beef: Factors, Determinants and Segments in Consumer Critisism of Advertising, Journal of Marketing, 57, 99-114.
Roedder J. D. - Cole, C. A. (1986): Age Differences in Information Processing:Understanding Deficit in Young and Elderly Consumers, Journal of Consumer Research, Vol. 13, December, 297-315.

Rokeach, M. J. (1968): The Role of Values in Public Opinion Research, Public Opinion Quarterly, 32, 547-549.

Rousseau, G. K. - Lamson, N. - Rogers, W. A. (1998): Designing Wamings to Compensate for Age-Related Changes in Perceptual and Cognitive Abilities, Psychology and Marketing, Oct., Vol. 15 (7), 643-662.

S. Molnár E. (2004): Életmód és közérzet az idősödés korában, in: Társadalmi riport 2004, Tárki, szerk: Kolosi Tamás, Tóth István György, Vukovics György, 152-164.

Sproles, G. B. - Kendall, E. (1986): A Methodology for Profiling Consumers' Decision-Making Styles, Journal of Consumer Affairs, 20, 267-279.

Sproles, E. K. - Sproles, G. B. (1990): Consumer Decision - Making Styles as a Function of Individual Leaming Styles, Journal of Consumer Affairs, 24, 134-147.

Törốcsik M. (2003): Fogyasztói trendek, KJK, Budapest Underbill, L. - Cadwell, F. (1984): „What age do you feel” Age perception study, Journal of Consumer Marketing, Vol. 2, Summer 18-27. 